\title{
Cellular Base Station Powered by Hybrid Energy Options
}

\author{
Raees M. Asif \\ Hamdard University \\ AK Fazl-e-Haq Road, Blue Area \\ Islamabad, Pakistan
}

\author{
Fahimullah Khanzada \\ Hamdard University \\ AK Fazl-e-Haq Road, Blue Area \\ Islamabad, Pakistan
}

\begin{abstract}
In this paper, the energy consumption issue of a cellular Base Transceiver Station (BTS) is addressed and a hybrid energy system is proposed for a typical BTS. Hybrid Optimization Model for Electric Renewable (HOMER Pro 3.1.2.0) is used to analyze different energy options and simulation results show that considering hybrid energy solution comprising of renewable and non-renewable energy solutions can lower the cost and accompanying $\mathrm{CO}_{2}$ emissions.
\end{abstract}

\section{General Terms}

Telecommunication, Mobile Communication, Renewable Energy

\section{Keywords}

Mobile communication, Base Station, Base Transceiver Station, Renewable Energy, HOMER

\section{INTRODUCTION}

Owing to technological development, effective telecommunication is being considered the nucleus of a country's social and economic prosperity. [10] For the growth of both global and national economy, growth in mobile phone penetration and tele-density is pertinent. [05] It is estimated that about 160 million people can be elevated from poverty and about 140 million new jobs can be created if worldwide connectivity is realized in today's booming global mobile economy. [01] [02] Telecommunication, is the largest industrial sector worldwide. [06] Cell phone usage has positive impact on personal income, employment opportunities, productivity growth and economic growth. [07] [08] [09] Studies have found that increase in mobile-phone penetration raised economic growth in India, China and European Union etc. [03]

Pakistan is considered an underdevelopment economy and for the economic growth, it is imperative to pave ways to increase cellular phone penetration and tele-density. [04] Since their introduction in late nineties, mobile-phone market has been growing and for every one percent increase in penetration GDP raises by 0.12 percent. [06] Telecommunication sector has $2.7 \%$ share in overall GDP, creates significant number of new jobs and Foreign Direct Investment (FDI) into the sector was US \$ 903 million in the year 2014. [04] [10] [01]

With an annual population growth rate of $2.05 \%$, it is estimated that Pakistan will be the fourth most popular nation by 2050 . [15] Presently the sixth most populous country, an annual growth rate of $2.05 \%$ will make Pakistan fourth largest nation in terms of population by 2050. [10] [15]. This further projects an increased demand in Information and Communication Technologies (ICT). [10]

Unfortunately Pakistan is mired in an acute energy crisis which has haltered economic progress for the last five years. [17] [15] An energy shortage of 5-7 GW plunges the population into frequent electric outages and it costs up to $4 \%$ of the GDP. [18] [17] In addition to have badly affected financial and operational facets of various industrial and commercial entities, energy crises also pose negative impacts for the telecommunication sector as stakeholders demand uninterrupted services. [04] [11]

In mobile telephony, Base Transceiver Station (BTS), commonly called 'tower' is important equipment which connects a mobile terminal to the relevant wireless operator. [10] From the operator's side, about $57 \%$ of the total energy is consumed by the Base Station. [13] Already an energydeficient country, provision of clean-power to the mobile Base Stations is a key issue in Pakistan. [12] [15] For operators to provide coverage in energy-scarce areas, an additional cost of developing power infrastructure is also imposed. Typically, diesel-generators are used which not only increases the expenditure but is also not environmentally friendly. [14] The most viable option would be to harness the abundantly available clean and renewable energy sources to power the Base Transceiver Stations (BTS) towers. According to recent studies, Pakistan can overcome its energy crises by taking bold steps to adopt renewable energy solutions. [15] [16] [19]

The study aims to find an optimum stand-alone hybrid energy solution to power a mobile Base Transceiver Station (BTS) in an urban setting such that its reliance on conventional diesel fuel is lowered. Hybrid Optimization Model for Electric Renewable (HOMER Pro 3.1.2.0) from National Renewable Energy Laboratory (NREL) has been used as software tool for finding the optimal energy solution. Technical and economical feasibility of employing hybrid renewable energy system (HRES) is presented.

The paper is organized as follows: Section 2 provides a brief description of renewable energy potential of the study area; Section 3 discusses the load profile and required components for modeling; Section 4 contains simulation results of HOMER and Section 5 concludes the work.

\section{RENEWABLE ENERGY POTENTIAL}

Pakistan has huge potential to utilize renewable energy sources such as solar, wind and water. [18] Considered as an ideal place to harness Solar Energy, average sunshine duration is 8-10 hours daily throughout most of the country. Solar energy received annually is about 1715 times higher than present primary energy consumption and potential for Solar PV installed capacity is $1600 \mathrm{GW}$. Average daily solar irradiation is $200-250 \mathrm{~W} / \mathrm{m}^{2}$. Hydropower is also abundantly available and has a theoretical potential of about $41.5 \mathrm{GW}$. Pakistan has considerable potential to harness wind power which is about 346,000 MW. [21] [22] [23] [20] Maximum wind speed in Pasni, Balochistan is $8 \mathrm{~m} / \mathrm{s}$. [20]

The location considered in this study is the country's capital, Islamabad. Its elevation is $\mathbf{5 4 0}$ meters and is located at the northern edge of Potohar Plateau. Islamabad has a humid subtropical climate with five seasons: Winter (NovemberFebruary), Spring (March and April), Summer (May and June), Rainy Monsoon (July and August) and Autumn (September and October) and average temperature range from 
$13{ }^{\circ} \mathrm{C}$ in January to $38{ }^{\circ} \mathrm{C}$ in June. To provide good living standards and for lower air pollution regulations prohibiting usage of 2-stroke vehicles have been implemented since its planning. [25] [24]

For HOMER to design the system, solar irradiation and wind speed of the area were provided as input. Average values of solar irradiation, wind speed and air temperature obtained from NREL dataset and Windfinder are given in Table 1: [26] [27]

Table 1: Average monthly values of wind speed, air temperature, clearness index and daily radiation [26] [27]

\begin{tabular}{|l|c|c|c|c|}
\hline Month & $\begin{array}{c}\text { Average } \\
\text { Wind } \\
\text { Speed } \\
(\mathbf{m} / \mathbf{s})[26]\end{array}$ & $\begin{array}{c}\text { Average } \\
\text { air } \\
\text { temperatu } \\
\text { re }\left({ }^{\circ} \mathbf{C}\right) \\
{[\mathbf{2 6}]}\end{array}$ & $\begin{array}{c}\text { Clearness } \\
\text { Index } \\
{[27]}\end{array}$ & $\begin{array}{c}\text { Daily } \\
\text { Radiation } \\
(\mathbf{k W h} / \mathbf{m} 2 / \mathbf{d a} \\
\mathbf{y})[27]\end{array}$ \\
\hline Jan & 5 & 13 & 0.585 & 3.099 \\
Feb & 6 & 16 & 0.601 & 3.971 \\
March & 6 & 22 & 0.573 & 4.789 \\
April & 6 & 26 & 0.589 & 5.909 \\
May & 6 & 33 & 0.617 & 6.855 \\
Jun & 6 & 35 & 0.614 & 7.072 \\
July & 6 & 33 & 0.544 & 6.136 \\
Aug & 6 & 30 & 0.519 & 5.401 \\
Sep & 5 & 29 & 0.611 & 5.448 \\
Oct & 5 & 26 & 0.654 & 4.652 \\
Nov & 4 & 21 & 0.629 & 3.511 \\
Dec & 4 & 16 & 0.537 & 2.626 \\
\hline
\end{tabular}

\section{MODELLING}

An average cellular base station can consume from $1 \mathrm{~kW}$ to 5 $\mathrm{kW}$ of electric power. [20] Table II shows power consumption of common mobile base stations: [28]

Table 2: Power consumption of common mobile base stations

\begin{tabular}{|l|l|}
\hline \multicolumn{1}{|c|}{ Type of Base Station } & $\begin{array}{l}\text { Typical power } \\
\text { consumption }\end{array}$ \\
\hline GSM Base Station 2/2/2 & $600-1800 \mathrm{~W}$ \\
GSM Base Station 4/4/4 & $900-2300 \mathrm{~W}$ \\
$\begin{array}{l}\text { UMTS Node B } \\
\text { Macro/Fiber 2/2/2 } \\
\text { Macro/Fiber - 4/4/4 }\end{array}$ & $750-1000 \mathrm{~W}$ \\
\hline
\end{tabular}

However, for our analysis, a Base Station which needs $2.5 \mathrm{~kW}$ of power is considered. Usually, the load pattern of BTS towers vary owing to variations in hourly weather patterns but for the worst case scenario, we consider a constant load of 2.5 $\mathrm{kW}$ with $4.5 \mathrm{~kW}$ as its peak value.

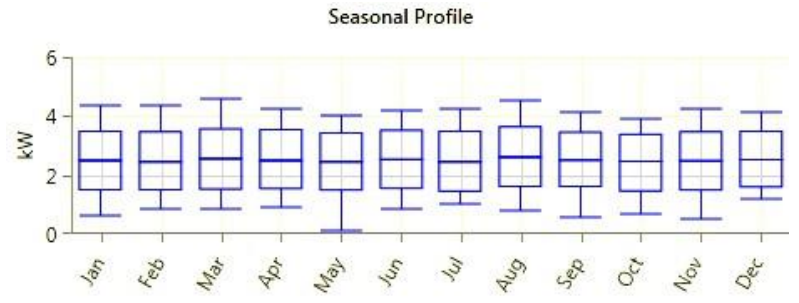

Figure 1: Seasonal load profile of the BTS

Figure 2 shows schematic of the system simulated in HOMER.

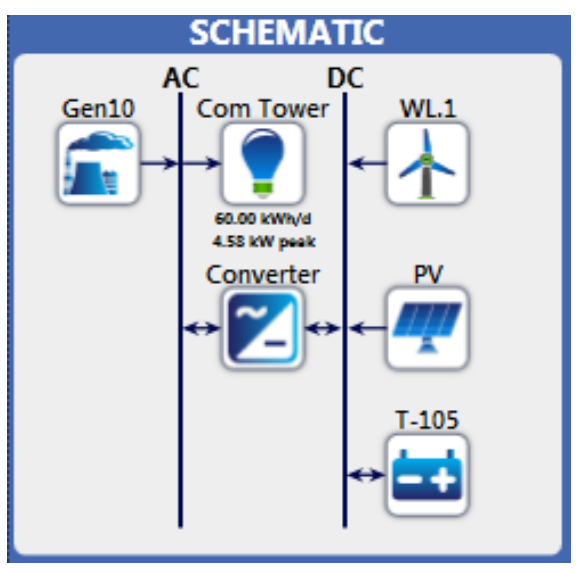

Figure 2: HOMER schematic of the system

Proposed system consists of renewable sources (wind turbine and solar photovoltaic), non-renewable sources (diesel generator and batteries) and converter to connect AC and DC links. Such energy sources can provide an uninterrupted power. Components along with relevant parameters assumed in the system design are shown in Table III.

For solar photovoltaic array, it is assumed that the system does not need a tracking system and following sizes are considered: 1, 2, 2.5 and $5 \mathrm{~kW}$ etc. A small-scale wind turbine having a capacity of $1 \mathrm{~kW}$ is considered and there can be 1,2 and/or 5 units. For battery back-up, up to 3 strings are considered and each has 8 batteries. With an initial cost of US $\$ 400 / \mathrm{kW}$, sizes of $1,2,3$ and $5 \mathrm{~kW}$ are considered for the diesel generator.

\section{SIMULATION RESULTS}

After providing the inputs, HOMER performed hourly simulation for each of the given energy options on the basis of operational characteristics such as annual electricity production, renewable fraction, Cost Of Energy (COE) and Net Present Cost (NPC) etc. HOMER ranks the energy options and optimum system configuration meeting the load requirement at lowest NPC is identified.

The salient features of each of the possible configuration are discussed as follows:

\section{1) PV/Wind/Diesel/Battery Hybrid System}

With Cost Of Energy (COE) as $\$ 0.839 / \mathrm{kWh}$, the hybrid energy case consisting of $5 \mathrm{~kW}$ PV, five $1 \mathrm{~kW}$ Wind Turbines, a $3 \mathrm{~kW}$ Diesel Generator, and 16 batteries has been identified as the optimum one. Its Net Present Cost is US \$ 600,516 and $48.1 \%$ contribution is from the renewable energy sources (Solar and Wind). Compared with others, in this configuration both diesel fuel consumption (3,962 liters) and operating costs $(\$ 17,041)$ are the minimum. An excess annual electricity of $3792.9 \mathrm{kWh}$ is produced. 
Table 3: Technical Data of Components

\begin{tabular}{|c|c|}
\hline \multicolumn{2}{|c|}{ Solar Photovoltaic (PV) } \\
\hline Size $(k W)$ & 1 \\
\hline Capital & US $\$ 1000$ \\
\hline Replacement & US \$ 700 \\
\hline Sizes to consider & $0,1,2,2.5,5$ \\
\hline Lifetime & 20 years \\
\hline Derating factor & 0.9 \\
\hline \multicolumn{2}{|c|}{ No tracking system installed } \\
\hline \multicolumn{2}{|c|}{ Wind Turbine } \\
\hline Model & BWC WL.1 \\
\hline Rated Capacity & $1 \mathrm{~kW}$ \\
\hline Initial cost per unit & US $\$ 6760$ \\
\hline Replacement cost & US \$ 4595 \\
\hline Maintenance cost & US \$25/year \\
\hline Units consideration & $0,1,2,4,5$ \\
\hline Life time & 15 years \\
\hline \multicolumn{2}{|c|}{ Battery } \\
\hline Model & T-105 \\
\hline Rating & $6 \mathrm{~V}, 225 \mathrm{Ah}, 1.35 \mathrm{kWh}$ \\
\hline Initial cost per unit & US \$ 174 \\
\hline Replacement cost & US \$ 174 \\
\hline Maintenance cost & US \$ 5/year \\
\hline Units consideration & $0,1,2,3$ strings \\
\hline Battery string & 8 batteries \\
\hline Lifetime & $865 \mathrm{kWh}$ \\
\hline \multicolumn{2}{|c|}{ Converter } \\
\hline Capital cost & US $\$ 200 / \mathrm{kW}$ \\
\hline Maintenance cost & US $\$ 10 / y r$ \\
\hline Sizes consideration & $1,2,5$ \\
\hline Lifetime & 10 years \\
\hline Efficiency & 0.9 \\
\hline \multicolumn{2}{|c|}{ Diesel Generator } \\
\hline Rating & $1 \mathrm{~kW}$ \\
\hline Sizes consideration & $1,2,3$ and $5 \mathrm{~kW}$ \\
\hline Maximum load ratio & 0.25 \\
\hline Initial cost per unit & US \$ 400/kW \\
\hline Replacement cost & US \$300/kW \\
\hline Operational cost & $0.75 / \mathrm{hr}$ \\
\hline
\end{tabular}

\begin{tabular}{|l|l|} 
Lifetime & $15000 \mathrm{hrs}$ \\
\hline Diesel price & US \$ 1/Liter \\
\hline
\end{tabular}

\section{2) PV/Diesel/Battery Hybrid System}

This hybrid system consists of $5 \mathrm{~kW}$ from PV array, $3 \mathrm{~kW}$ diesel generator and 16 batteries. In this case COE is $\$ 0.939$ i.e. \$ 0.10 higher than the previous case. Here, renewable energy fraction is reduced to $29.4 \%$ and both NPC and operating costs have increased.

\section{3) Wind/Diesel/Battery}

This hybrid system uses five $1 \mathrm{~kW}$ small-scale wind turbines, $3 \mathrm{~kW}$ diesel generator and 24 batteries. Now, COE, NPC and Operating Costs are \$1.041, \$ 744,238 and \$21,550 respectively. The renewable fraction has further reduced to $22.7 \%$ and the generator has to consume 5,720 liters of diesel fuel.

\section{4) Diesel/Battery}

In this non-renewable hybrid system, $3 \mathrm{~kW}$ diesel generator and 24 batteries are used. Initial capital is $\$ 5,776$ which is the most minimum among all options and $\mathrm{COE}$ is $\$ 1.205$. Annual excess electricity in this case is less than $1 \mathrm{kWh}$.

\section{5) PV/Wind/Diesel}

In this hybrid system, battery is not considered and COE is \$ $1.684 / \mathrm{kWh}$. The renewable energy fraction is $34.8 \%$ and ranks second after the optimum case. Renewable energy fraction here is $34.8 \%$ and an excess electricity of 8036 $\mathrm{kWh} /$ year, which is about $4244 \mathrm{kWh}$ more than that of the most optimum case, is produced in this case.

HOMER also measured the accompanying $\mathrm{CO}_{2}$ emissions and the values are shown in Table 4 .

Table 4: $\mathrm{CO}_{2}$ Emissions associated with the energy options

\begin{tabular}{|c|c|}
\hline \multicolumn{2}{|c|}{ CO $_{2}$ Emissions } \\
\hline $\begin{array}{c}\text { PV/Wind/Diesel/Battery } \\
\text { Hybrid System }\end{array}$ & $10,432 \mathrm{~kg} / \mathrm{year}$ \\
\hline $\begin{array}{c}\text { PV/Diesel/Battery } \\
\text { Hybrid System }\end{array}$ & $13,945 \mathrm{~kg} / \mathrm{year}$ \\
\hline $\begin{array}{c}\text { Wind/Diesel/Battery } \\
\text { Hybrid System }\end{array}$ & $15,063 \mathrm{~kg} / \mathrm{year}$ \\
\hline $\begin{array}{c}\text { Diesel/Battery Hybrid } \\
\text { System }\end{array}$ & $20,116 \mathrm{~kg} / \mathrm{yr}$ \\
\hline $\begin{array}{c}\text { PV/Wind/Diesel } \\
\text { Hybrid System }\end{array}$ & $15,505 \mathrm{~kg} / \mathrm{yr}$ \\
\hline
\end{tabular}

Figure 3 shows the optimization result obtained from HOMER ranked according to the lowest Net Present Cost (NPC). It can be observed that in an area having average Global Horizontal Irradiance (GHI) of $4.96 \mathrm{kWh} / \mathrm{m} 2 /$ day, average wind speed of $5.42 \mathrm{~m} / \mathrm{s}$, average temperature of $25 \mathrm{C}$ and diesel fuel priced at $\$ 1 /$ liter, the most optimum energy solution having the least Cost Of Energy (COE) is the one having $5 \mathrm{~kW}$ from Solar Photovoltaic (PV), $5 \mathrm{~kW}$ from Wind, $3 \mathrm{~kW}$ from Diesel Generator and sixteen $1 \mathrm{kWh}$ batteries. 
Data of accompanying $\mathrm{CO}_{2}$ emissions are the lowest for the first case, thus making it the cleanest option in addition to its being the optimum case.

\begin{tabular}{|c|c|c|c|c|c|c|c|c|c|c|c|c|c|c|c|c|c|}
\hline \multicolumn{11}{|c|}{ Architecture } & \multicolumn{4}{|c|}{ Cost } & System & \multicolumn{2}{|c|}{ Gen10 } \\
\hline$m$ & t & E & 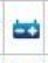 & z & $\underset{(\mathrm{kW})}{\mathrm{PV}} \mathrm{\nabla}$ & ${ }_{(q t y)}^{\text {WL.1 }} \nabla$ & $\begin{array}{c}\text { Gen10 } \\
(\mathrm{kW})\end{array}$ & $\begin{array}{c}\text { T-105 } \\
\text { (qty) }\end{array}$ & $\begin{array}{c}\text { Converter } \\
(\mathrm{kW})\end{array}$ & Dispatch $\nabla$ & $\underset{(\$ / k W h)}{\operatorname{COE}} \nabla$ & $\begin{array}{c}N P C \\
(\$)\end{array}$ & $\begin{array}{c}\text { Operating Cost } \\
(\$)\end{array}$ & $\begin{array}{c}\text { Initial Capital } \checkmark \\
\text { (\$) }\end{array}$ & $\begin{array}{c}\text { Ren Frac } \nabla \\
(\%)\end{array}$ & $\begin{array}{c}\text { Fuel } \nabla \\
\text { (L) }\end{array}$ & Hours $\checkmark$ \\
\hline 需 & 个 & E & tet & $\boldsymbol{z}$ & 5.0 & 5 & 3 & 16 & 5 & $\mathrm{CC}$ & $\$ 0.839$ & $\$ 600,516$ & $\$ 17,041$ & $\$ 43,784$ & 48.1 & 3,962 & 4,938 \\
\hline 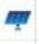 & & $E$ & 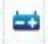 & $\boldsymbol{z}$ & 5.0 & & 3 & 16 & 5 & $\mathrm{CC}$ & $\$ 0.939$ & $\$ 671,947$ & $\$ 20,261$ & $\$ 9,984$ & 29.4 & 5,295 & 6,079 \\
\hline & t & $=$ & $t$ & $\boldsymbol{z}$ & & 5 & 3 & 24 & 5 & $c c$ & $\$ 1.041$ & $\$ 744,238$ & $\$ 21,550$ & $\$ 40,176$ & 22.7 & 5,720 & 6,100 \\
\hline & & E & $t$ & $\tilde{z}$ & & & 3 & 24 & 2 & $\mathrm{CC}$ & $\$ 1.205$ & $\$ 862,053$ & $\$ 26,209$ & $\$ 5,776$ & 0 & 7,639 & 7,861 \\
\hline m & 个 & $E$ & & $\boldsymbol{z}$ & 5.0 & 5 & 5 & & 5 & $\mathrm{CC}$ & $\$ 1.684$ & $\$ 1,204,831$ & $\$ 35,599$ & $\$ 41,800$ & 34.8 & 5,888 & 7,525 \\
\hline PI & & . & & z & 5.0 & & 5 & & 5 & $\mathrm{CC}$ & $\$ 1.750$ & $\$ 1,252,335$ & $\$ 38,087$ & $\$ 8,000$ & 22.5 & 6,800 & 8,113 \\
\hline & t & $E$ & & z & & 1 & 5 & & 1 & $\mathrm{CC}$ & $\$ 1.922$ & $\$ 1,375,494$ & $\$ 41,828$ & $\$ 8,960$ & 5.6 & 8,015 & 8,760 \\
\hline
\end{tabular}

Figure 3: HOMER result for evaluating the optimized case

\section{CONCLUSION}

Various options for powering a cellular BTS are considered in this paper. From techno-economic analysis, it was found that a hybrid energy system consisting of Solar PV, Small-scale wind, diesel and batteries is the optimal one in an urban setting. Besides, it is environmentally friendly with the least $\mathrm{CO}_{2}$ emission. Utilizing renewable energy options in combination with conventional diesel and batteries can not only lower the energy cost but also reduces the accompanying greenhouse gas emissions. Suchlike cleaner energy options should be considered for powering cellular Base Transceiver Stations (BTS) and there is a need for telecom operators to consider incorporating such targets into their plans. The idea of evaluating feasibility of alternative energy options for cellular Base Stations should also be expanded to rural areas of the country and the chosen energy options should include biomass, hydrogen storage and solar thermal energy systems.

\section{REFERENCES}

[1] West, Darrell M. "The State of the Mobile Economy, 2014: Its Impact and Future." (2014).

[2] A.T. Kearney Analysis, "GSMA The Mobile Economy," 2012.

[3] Shakeel, Mohsin, Raja Abdul Ghafoor Khan, and Dr Haniya Rehman Malik. "Telecommunications Role in Economic Growth with Respect to Pakistan." Global Journal of Management And Business Research 12.19 (2012).

[4] Fahad Ahmed (2012). Telecommunication Sector- Its Role, Contribution To Fbr Revenue, Problems And Issues. Online available at http://www.dgtrdt.gov.pk/Research/37th_synndicate_\%2 Orports/6.pdf.

[5] Hashim, Shumaila, Akhtar Munir, and Afnan Khan. "Telecom Infrastructure and economic development of Pakistan: An empirical Analysis." International research journal of Arts and Humanities 37 (2009): 147-156.

[6] Malik, Shahnawaz, Imran Sharif Chaudhry, and Qaiser Abbas. "Socio-economic impact of cellular phones growth in Pakistan: an empirical analysis." Pakistan Journal of Social Sciences (PJSS) 29.1 (2009): 23-37.

[7] Madden, G. and Savage, S. (2000). Telecommunications and economic growth. International Journal of Social Economics, 27(7-10), 893-906.

[8] Sridhar, Kala Seetharan \& Sridhar, Varadharajan (2007). Telecommunications Infrastructure and Economic
Growth: Evidence from Developing Countries. Applied Econometrics and International Development, EuroAmerican Association of Economic Development, 7(2), 37-56.

[9] Gruber, H., \& Koutroumpis,P. (2010). Mobile Telecommunications and the Impact on Economic Development: Economic Policy Fifty-Second Panel Meeting,Hosted by EIEF.

[10] Pakistan telecommunication authority (PTA) annual report. (2014). [Online] Available: www.pta.gov.pk

[11] The Express Triune, (2013). Responsible power generation: Cellular industry's shift towards green energy. [online] Available at: http://tribune.com.pk/story/595078/responsible-powergeneration-cellular-industrys-shift-towards-green-energy/ [Accessed 21 Mar. 2015].

[12] Motorola Reach, "Alternative Power for Mobile Telephony Base Stations" Solution Paper, 2007.

[13] Ismail, Muhammad, et al. "A Survey on Green Mobile Networking: From The Perspectives of Network Operators and Mobile Users."

[14] Mcmilin, Emily. "Powering Mobile Base Stations."

[15] Bhutto, Abdul Waheed, Aqeel Ahmed Bazmi, and Gholamreza Zahedi. "Greener energy: Issues and challenges for Pakistan-Biomass energy prospective." Renewable and Sustainable Energy Reviews 15.6 (2011): 3207-3219.

[16] Chaudhry, M. Ashraf, R. Raza, and S. A. Hayat. "Renewable energy technologies in Pakistan: prospects and challenges." Renewable and Sustainable Energy Reviews 13.6 (2009): 1657-1662.

[17] Hasan, Mirza Hamid, "An Overview of Pakistan's Energy Sector: Policy Perspective." Solutions for Energy Crisis in Pakistan, May 15-16, 2013. Islamabad: Islamabad Policy Reserach Institute, n.d. Print.

[18] Harijan, Khanji. "Renewable Energy in Pakistan: Potential and Prospects." Solutions for Energy Crisis in Pakistan, May 15-16, 2013. Islamabad: Islamabad Policy Reserach Institute, n.d. Print.

[19] Khan, Shaukat Hameed. "Energy Vision 2030." Solutions for Energy Crisis in Pakistan, May 15-16, 2013. Islamabad: Islamabad Policy Reserach Institute, n.d. Print. 
[20] Ahmed, M. Akhlaque, and Firoz Ahmad "ESTIMATION OF WIND POWER POTENTIAL FOR PASNI, COAST OF BALUCHISTAN, PAKISTAN." Journal of Research (Science): 455-460.

[21] Pakistan Energy Year Book, Ministry of Petroleum \& Natural Resources, Hydrocarbon Development Institute of Pakistan, (Govt. of Pakistan. 2004).

[22] P.J.Musgrove, Solar and Wind Technology, 4, (1987), 37.

[23] Wentink, Final Report, (1976), Report no. NSF/RANN /SE/AER 74-0039 /R-76/1, Geophysical Institute, University of Alaska

[24] Frantzeskakis, I. M. "Islamabad, a town planning example for a sustainable city." Sustainable Development and Planning Iv, Vols 1 and 2.120 (2009): 75-85.
[25] Siddique, N., et al. "Air quality study of Islamabad: preliminary results." Journal of Radioanalytical and Nuclear Chemistry 293.1 (2012): 351-358.

[26] "Wind and Weather Statistic Islamabad/Rawalpindi Airport." Windfinder.com. N.p., n.d. Web. 23 Mar. 2015. $<$ http://www.windfinder.com/windstatistics/islamabad_ra walpindi_airport>.

[27] "Pakistan Resource Maps and Toolkit." NREL: International Activities. National Renewable Energy Laboratory (NREL), n.d. Web. 24 Mar. 2015. <http://www.nrel.gov/international/ra_pakistan.html>.

[28] Saxena, Tushar, J. S. Jadon, and M. Student. "Different Power Supply Planning Options Available for a BTS Site" 